\title{
Prosedur Pengajuan Akad Rahn Pada Emas Batangan Di PT Bank Syariah Mandiri Cabang Rawamangun
}

\author{
Nidaul Izzah, Savira Nurul Annisa \\ Institut Ilmu Sosial dan Manajemen Stiami \\ Email : nida.achis@yahoo.com, nurulannissavira@gmail.com
}

\section{ARTICLE INFO}

Keywords

Procedure, Submission,

Pawnshop

\section{ABSTRACT}

The final report written based on observation in PT Sharia Bank Mandiri Rawamangun branch. Observation methods conducted with observations and interview related to convenant on gold bars. The purpose of this reservation is to know the filing procedures of convenant on gold bars in PT Sharia Bank Mandiri. To apply for gold pawn financing in PT Sharia Bank Mandiri Rawamangun branch, customer comes to the branch office to fill out the application form and attach some requirements like identity card, NPWP card if the financing is above 50 million, have a saving account and warranty of gold bars. In this case, so gold pawn financing can familiar in public especially the middle to lower society then need to socialization and promotion like opening outlets on campus, central business and shopping center.

\section{PENDAHULUAN}

Pada zaman modern ini kebutuhan masyarakat meningkat tetapi tidak seiring dengan pendapatan mereka, sehingga utang-piutang terkadang tidak dapat dihindari, padahal banyak muncul fenomena ketidakpercayaan diantara manusia khususnya di zaman sekarang ini. Realita yang ada tidak dapat dipungkiri, suburnya usaha-usaha pegadaian baik dikelola pemerintah atau swasta menjadi bukti terjadinya kegiatan gadai ini. Ironisnya, banyak kaum muslim yang belum mengenal aturan indah dan adil dalam islam mengenai gadai. Padahal perkara ini bukanlah perkara baru dalam kehidupan dan sebagai akibatnya banyak terjadi kezaliman dan saling memakan harta saudaranya secara bathil.

Produk gadai emas di Bank Syariah Mandiri tentunya menjadi salah satu alternatif memperoleh uang tunai dengan cepat dan menentramkan. Menentramkan karena sumber dana yang dimiliki didapat dari sumber dana yang halal dan sesuai dengan prinsip syariah. Gadai emas yang dimiliki Bank Syariah Mandiri hanya menerima jaminan berupa emas minimal 16 karat untuk perhiasan dan 24 karat untuk lantakan/batangan.

Produk gadai emas di Bank Syariah Mandiri tentunya memiliki keunggulan tersendiri dari pegadaian emas lainnya. Nasabah akan mendapat layanan yang aman dan terjamin, pricing yang murah, proses yang mudah dan cepat.

Jika masyarakat mau melihat keadaan lembaga formal yang dapat dipergunakan untuk melakukan pinjam-meminjam, mungkin masyarakat akan cenderung memilih lembaga formal untuk memenuhi kebutuhan dananya. Lembaga formal tersebut dibagi menjadi dua yaitu lembaga bank dan lembaga non-bank. Saat ini masih terdapat kesan pada masyarakat bahwa meminjam ke bank adalah suatu hal yang lebih membanggakan dibandingkan dengan lembaga formal lain, padahal dalam proses nyatanya memerlukan waktu yang relatif lama dengan persyaratan yang cukup rumit serta jaminan yang memberatkan. Padahal pemerintah telah memfasilitasi masyarakat dengan suatu perusahaan umum (perum) yang telah melakukan kegiatan pegadaian yaitu perum pegadaian yang menawarkan akses yang lebih mudah, proses yang jauh lebih singkat dengan persyaratan yang relatif sederhana dan mempermudah masyarakat dalam memenuhi kebutuhan dana. Selama ini banyak orang yang merasa malu dan canggung untuk datang ke kantor pegadaian terdekat. Hal ini tidak terlepas dari sejarah PT Pegadaian yang awalnya merupakan sarana alternatif bagi masyarakat ekonomi lemah untuk memperoleh pinjaman uang secara aman dan praktis dengan hanya menggadaikan barang berharganya. Tidak mengherankan bila yang datang ke kantor pegadaian pada umumnya adalah orang-orang yang berpenampilan lusuh dengan wajah tertekan. 
Secara umum faktor penyebab rendahnya minat masyarakat dalam memanfaatkan jasa pegadaian ini, diduga salah satunya karena faktor minimnya pengetahuan masyarakat atas produk yang ditawarkan serta minimnya promosi yang dilakukan pihak manajemen perusahaan dalam memperkenalkan produk-produk yang dimaksud. Namun belakangan ini kesan tersebut perlahan sirna seiring dengan upaya modernisasi dan profesionalisasi yang dilakukan pihak PT Pegadaian. Kini mereka mulai membangun citra barunya sebagai sebuah lembaga keuangan yang profesional dengan mengusung motto "Menyelesaiakan masalah tanpa masalah". Demikian pula kalangan nasabahnya, tidak lagi terlepas dari golongan ekonomi menengah ke bawah tetapi malah menjangkau kalangan ekonomi atas. Jika dianalisa, hal ini tidak terlepas dari kebijakan pengembangan produk layanannya yang semakin kompleks, yaitu tidak hanya mencakup jasa gadai tapi juga taksiran, jasa titipan, jasa lelang, dan tidak ketinggalan jasa layanan galerinya, yakni toko emas yang menjual emas berkualitas. Secara umum lembaga pegadaian dimaksudkan sebagai suatu lembaga yang memberikan fasilitas bagi warga masyarakat untuk dapat memperoleh pinjaman uang secara praktis. Pada prinsipnya, ketika kita melakukan tranksaksi gadai, kita menyerahkan barang yang kita gadai, kita menyerahkan barang yang kita miliki untuk mendapatkan pinjaman dana. Atas pinjaman tersebut, kita dibebankan beberapa macam biaya hingga waktu kita bisa melunasi pinjaman tersebut.

Sejarah pegadaian syariah di Indoneisa tidak dapat dipisahkan dari kemauan warga masyarakat Islam untuk melaksanakan transaksi akad gadai berdasarkan prinsip hukum Islam. Hal ini dimaksud, dilatarbelakangi oleh maraknya aspirasi dari warga masyarakat Islam di berbagai daerah yang dan menginginkan pelaksanaan hukum Islam dalam berbagai aspeknya. termasuk pegadaian syariah. Selain itu, semakin populernya praktis bisnis ekonomi syariah dan mempunyai peluang yang cerah untuk dikembangkan. Melihat semakin berkembangnya permintaan masyarakat dan kian diterimanya pola bisnis berbasis syariah dalam praktek perekonomian di Indonesia, maka banyak Bank dan Lembaga Keuangan lainnya tertarik untuk menerapkan pola serupa. Apalagi, pola pegadaian syariah memungkinkan perusahaan dapat lebih proaktif dan lebih produktif dalam menghasilkan berbagai produk jasa keuangan modern, seperti jasa piutang dan jasa sewa beli. Pada lembaga gadai model yang dimaksud, nilai-nilai dan prinsip syariah dalam hal gadai dapat di implementasikan. Selain itu fungsinya juga dapat dipertimbangkan sebagai lembaga intermediasi bagi warga masyarakat terhadap sektor keuangan. Salah satu keuntungan investasi emas adalah begitu banyak fasilitas pembiayaan yang tersedia dan dapat juga kita gunakan sewaktu-waktu dengan cepat. Maka jika kita mempunyai simpanan dalam bentuk emas dan suatu saat ada kebutuhan dana mendesak, kita tidak perlu serta merta menjual emas yang kita miliki untuk menutupi kebutuhan tersebut. Kita bisa mendapatkan pinjaman dana cepat dengan menggadaikan emas yang kita miliki.

Berdasarkan uraian diatas, maka penulis tertarik melakukan pengamatan dengan mengangkat judul

"Prosedur Pengajuan Akad Rahn Pada Emas Batangan di PT Bank Syariah Mandiri Cabang Rawamangun".

\section{Fokus Pengamatan}

Dari uraian-uraian latar belakang di atas, maka dapat dirumuskan fokus pengamatan sebagai berikut :

1. Bagaimana prosedur pengajuan akad rahn pada emas batangan di PT Bank Syariah Mandiri Cabang Rawamangun?

2. Apa kendala dalam pelaksanaan prosedur pengajuan akad rahn pada emas batangan di PT Bank Syariah Mandiri Cabang Rawamangun?

3. Bagaimana solusi untuk mengatasi kendala dalam pelaksanaan prosedur pengajuan akad rahn pada emas batangan di PT Bank Syariah Mandiri Cabang Rawamangun?

\section{Tinjauan Literatur}

Menurut Soetjipto (2015:16) "Prosedur merupakan serangkaian tahapan dalam penyelesaian pekerjaan yang harus dilalui, dari mana asalnya dan mau menuju kemana, kapan pekerjaan tersebut harus diselesaikan, alat apa yang harus digunakan agar pekerjaan tersebut dapat diselesaikan secara efektif."

Menurut Mulyadi (2013:5)

"Prosedur adalah suatu urutan kegiatan klerikal, biasanya melibatkan beberapa orang dalam satu departemen atau lebih, yang dibuat untuk menjamin penanganan secara seragam transaksi perusahaan yang terjadi berulang-ulang."

\section{Akad Rahn}

Nidaul Izzah .... (Prosedur Pengajuan Akad Rahn Pada Emas Batangan Di Pt Bank Syariah) 
Secara lughawi, makna al-aqd adalah perikatan, perjanjian, pertalian, permufakatan (al-ittifaq). Sedangkan secara istilahi, akad didefinisikan dengan redaksi yang berbeda-beda. Berbagai definisi tersebut dapat dimengerti bahwa, akad adalah pertalian ijab dan kabul dari pihak-pihak yang menyatakan kehendak sesuai dengan kehendak syariat yang akan memiliki akibat hukum terhadap obyeknya.

Persoalan akad adalah persoalan antar pihak yang sedang menjalin ikatan. Untuk itu yang perlu diperhatikan dalam menjalankan akad adalah terpenuhnya hak dan kewajiban dan masing-masing pihak tanpa ada pihak yang terlanggar haknya. Disinilah pentinya membuat batasan-batasan yang menjamin tidak terlanggarnya hak antar pihak yang sedang melaksanakan akad.

\section{Rukun Akad}

Rukun adalah unsur-unsur yang membentuk terjadinya akad. Tidak adanya rukun menjadikan tidak adanya akad. Jumhur Ulama' berpendapat bahwa rukun akad terdiri dari :1) Al-Aqidain (pihak-pihak yang berakad) 2) Obyek Akad 3) Sighat Al-Aqd (pernyataan untuk mengikat diri) 4) Tujuan Akad

\section{Syarat Akad}

Beberapa unsur dalam akad yang kemudian dikenal sebagai rukun tersebut masing-masing membutuhkan syarat agar akad dapat terbentuk dan mengikat antar pihak. Beberapa syarat tersebut meliputi :

1) Syarat terbentuknya akad dalam Hukum Islam syarat ini dikenal dengan nama al-syuruth al-in'iqad. Syarat ini terikat dengan sesuatu yang harus dipenuhi oleh rukun-rukun akad, yaitu : Pihak yang berakad, disyaratkan tamyiz dan berbilang., Shighat akad (pernyataan kehendak) adanya kesesuaian ijab dan kabul dan dilakukan dalam satu majlis akad, Obyek akad dalam diserahkan dapat ditentukan dapat ditransaksikan (benda yang bernilai dan dimiliki), Tujuan akad tidak bertentangan dengan syara'.

2) Syarat keabsahan akad, adalah syarat tambahan yang dapat mengabsahkan akad setelah syarat in'iqad tersebut dipenuhi. Setelah rukun akad terpenuhi beserta beberapa persyaratannya yang menjadikan akad terbentuk maka akad sudah terwujud. Akan tetapi ia belum dipandang sah jika tidak memenuhi syaratsyarat tambahan yang terkait dengan rukun-rukun akad, yaitu : Pernyataan kehendak harus dilaksanakan secara bebas. Jika pernyataan kehendak tersebut dilakukan dengan terpaksa, maka akad dianggap fasid, Penyerahan obyek tidak menimbulkan mudharat, bebas dari gharar, adalah tidak adanya tipuan yang dilakukan oleh para pihak yang berakad, bebas dari riba.

\section{Rahn}

Secara etimologi dalam bahasa Arab, kata ar-rahn berarti "tetap" dan "lestari". Kata ar-rahn juga dinamai al-habsa artinya "penahanan", seperti dikatakan ni'matul rahinah, artinya "karunia yang tetap dan lestari". Pengertian yang terkandung dalam istilah tersebut "menjadikan barang yang mempunyai nilai harta menurut pandangan syara' sebagai jaminan utang, hingga orang yang bersangkutan boleh mengambil uang atau ia bisa mengambil sebagian manfaat barang itu. Ar-rahn adalah salah satu harta si peminjam sebagai jaminan atas yang diterimanya. Barang yang ditahan tersebut memiliki nilai ekonomis.

Menurut Otoritas Jasa Keuangan tahun 2012, gadai adalah suatu hak yang diperoleh Perusahaan Pegadaian atas suatu barang bergerak, yang diserahkan kepadanya oleh nasabah atau oleh kuasanya, sebagai jaminan atas pinjamannya, dan yang memberi wewenang kepada Perusahaan Pegadaian untuk mengambil pelunasan pinjaman dari barang itu dengan mendahului kreditur-kreditur lain.

Menurut Undang-undang Hukum Perdata Pasal 1150, gadai adalah hak yang diperoleh seorang yang mempunyai piutang atas suatu barang bergerak. Barang gerak tersebut diserahkan kepada orang yang berpiutang oleh seorang yang mempunyai utang atau oleh seorang lain atas nama orang yang mempunyai utang. Seorang yang berutang tersebut memberikan kekuasaan kepada orang berpiutang untuk menggunakan barang bergerak yang telah diserahkan untuk melunasi utang apabila pihak yang berutang tidak memenuhi kewajibannya pada saat jatuh tempo.

Rukun akad rahn menurut Afandi (2010:151) : (a) Ar-rahin (yang menggadaikan) adalah orang yang telah dewasa, berakal, bisa dipercaya, dan memiliki barang yang akan digadaikan. (b) Al-murtahin (yang menerima gadai) adalah orang, bank atau lembaga yang dipercaya oleh rahin untuk mendapatkan modal dengan jaminan barang.(c) Al-marhun (barang yang digadaikan) adalah barang yang digunakan rahin untuk dijadikan jaminan dalam mendapatkan sejumlah dana atau hutang. (d) Al-marhun bih (utang) adalah sejumlah dana yang diberikan murtahin kepada rahin atas dasar besarnya taksiran marhun. (e) Sighat (ijab dan qabul) adalah kesepakatan antara rahin dan murtahin 
Syarat akad rahn menurut Afandi (2010:152) : (1) Rahin dan Murtahin Pihak-pihak yang melakukan perjanjian rahn, yaitu rahin dan murtahin harus mengikuti syarat-syarat beserta kemampuan, yaitu berakal sehat. Kemampuan juga berarti kelayakan seseorang untuk melakukan transaksi pemilikan. (2) Sighat, Sighat tidak boleh terikat dengan syarat tertentu dan waktu yang akan datang. Misalnya, orang yang menggadaikan hartanya mempersyaratkan tenggang waktu hutang habis dan hutang belum terbayar, sehingga pihak penggadai dapat diperpanjang satu bulan tenggang waktunya kecuali jika syarat itu mendukung kelancaran akad maka diperbolehkan.(3) Marhun bih (utang) harus merupakan hak yang wajib diberikan atau diserahkan kepada pemiliknya. (4) Memungkinkan pemanfaatan. Bila sesuatu menjadi utang tidak bisa dimanfaatkan, maka tidak sah. (5) Harus dikuantifikasi atau dapat dihitung jumlahnya. Bila tidak dapat diukur, maka rahn itu tidak sah. (6) Marhun (barang) Agunan itu harus mempunyai nilai ekonomis dan dapat dimanfaatkan menurut ketentuan syariat Islam, sebaliknya agunan yang tidak bernilai dan tidak dapat dimanfaatkan menurut syariat Islam maka tidak dapat dijadikan agunan.

\title{
Penyelesaian Ongkos dan Biaya Penyimpanan
}

Menurut Dr. Ade Sofyan Mulazid (2016:20), sistem pembayaran ongkos dan biaya yang berjalan di pegadaian syariah berbeda dengan pegadaian konvensional. Nasabah yang tidak mempunyai kemampuan membayar, ia tidak akan dikenakan bunga atas pinjaman, akan tetapi dikenakan biaya sewa penitipan, pemeliharaan, dan penjagaan atas barang yang digadaikan. Selanjutnya, jika setelah ditangguhkan, ternyata ia masih belum mampu membayar ongkos dan biaya penyimpanan, maka barang yang digaikan itu akan dilelang atau dijual untuk menutupi biaya-biaya tersebut. Apabila ada kelebihan sisa dari uang lelang diatas, maka akan dikembalikan kepada nasabah. Namun jika uang kelebihan dalam satu tahun tidak diambil, maka uang tersebut akan diserahkan kepada lembaga ZIS (zakat, infaq, dan shadaqah) sebagai denda. Begitupun sebaliknya apabila harga penjualan barang kurang dari jumlah biaya-biaya yang dikeluarkan, maka nasabah harus menanggung kekurangannya. Sayyid Sabiq menambahkan bahwa penyelesaian ongkos dan biaya penyimpanan barang dapat dilakukan dengan cara pertanggungan atau garansi pembayaran utang oleh orang lain. Pembayaran seperti ini dapat timbul karena rasa kesetiakawanan, atau adanya hubungan materiel antara penanggung daan ditanggung sehingga kedua belah pihak mengatur pertanggungan itu.

Dari penjelasan penyelesaian ongkos dan biaya penyimpanan barang diatas, pegadaian syariah bisa saja menambah cara baru untuk mengatasi kasus nasabah bermasalah, yaitu dengan pola hiwalah dan kafalah. Kedua cara penyelesaian ini sesuai dengan Al-Qur'an dan Hadist dan telah diadopsi oleh bank syariah. Penulis berasumsi bahwa dengan penggunaan pola penyesuaian diatas, tidak akan merugikan para pihak, baik pegadaian syariah maupun nasabah, keduanya akan diuntungkan.

Dasar hukum yang menjadi landasan rahn (gadai) adalah sebagai berikut :

Surat Al-Baqarah ayat 283 yang digunakan sebagai dasar dalam membangun konsep gadai adalah sebagai berikut

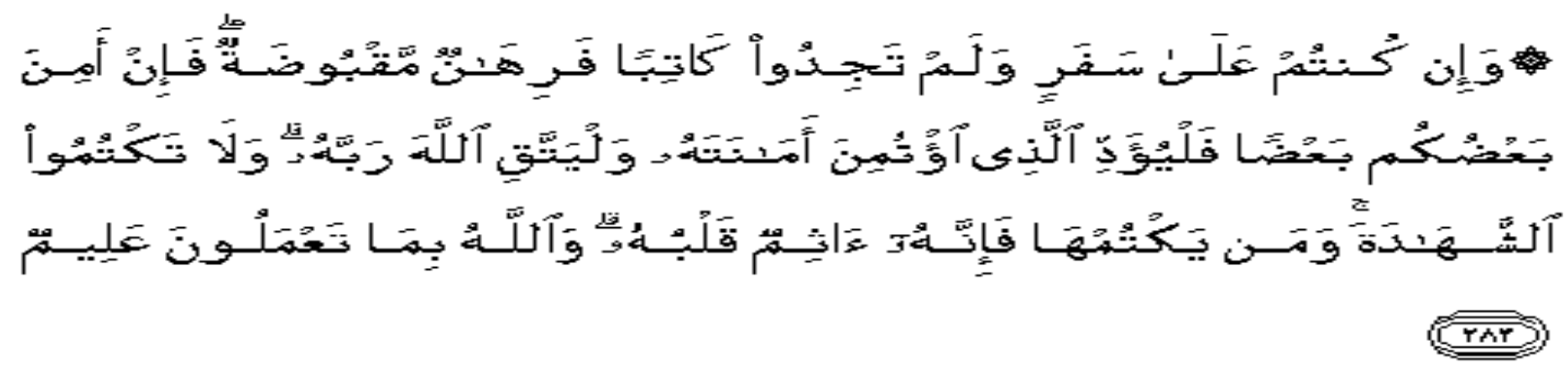

\begin{abstract}
"Jika kamu dalam perjalanan (dan bermu'amalah tidak secara tunai) sedang kamu tidak memperoleh seorang penulis, maka hendaklah ada barang tanggungan yang dipegang (oleh yang berpiutang), akan tetapi jika sebagian kamu mempercayai sebagian yang lain, maka hendaklah yang dipercayai itu menunaikan amanatnya (utangnya) dan hendaklah ia bertakwa kepada Allah Tuhannya dan janganlah kamu (para saksi) menyembunyikan persaksian. Dan barang siapa yang yang menyembunyikannya, maka sesungguhnya ia adalah orang yang berdosa hatinya dan Allah maha mengetahui apa yang kamu kerjakan."
\end{abstract}

Hadist Nabi Muhammad SAW

Dasar hukum yang kedua untuk dijadikan rujukan dalam membuat rumusan gadai syariah adalah hadist.

Nidaul Izzah .... (Prosedur Pengajuan Akad Rahn Pada Emas Batangan Di Pt Bank Syariah) 
a) Bukhari dan lainnya meriwayatkan dari Aisyah berkata "Rasulullah pernah membeli makanan dari orang Yahudi dan beliau menggadaikan kepadanya baju besi beliau." (HR. Bukhari dan Muslim)

b) Dari Anas ra berkata, "Rasulullah saw menggadaikan baju besinya kepada seorang Yahudi di Madinah dan mengambil darinya gandum untuk keluarga beliau." (HR. Bukhari, Ahmad, Nasa"i dan Ibnu Majah).

c) Dari Abu Hurairah ra bahwasanya Rasulullah saw berkata, "barang yang digadaikan itu tidak boleh disembunyikan dari pemilik yang menggadaikannya. Baginya adalah keuntungan dan tanggung jawabnya ialah bila ada kerugian (atau biaya).” (HR. Syafii dan Daruquth)

Fatwa Dewan Sayraih Nasional (DSN)

Fatwa Dewan Syariah Nasional Majelis Ulama Indonesia (DSN-MUI) menjadi salah satu rujukan yang berkenaan dengan gadai diantaranya sebagai berikut :

a) Fatwa Dewan Syariah Nasional Majelis Ulama Indonesia No.25/DSN-MUI/III/2002, tentang Rahn.

"Dewan Syariah Nasional menimbang bahwa salah satu bentuk jasa pelayanan keuangan yang menjadi kebutuhan masyarakat adalah pinjaman dengan menggadaikan barang sebagai jaminan utang."

b) Fatwa Dewan Syariah Nasional Majelis Ulama Indonesia No.26/DSN-MUI/III/2002, tentang Rahn Emas.

"Dewan Syariah Nasional menimbang bahwa masyarakat pada umumnya telah lazim menjadikan emas sebagai barang berharga yang disimpan dan menjadikannya objek rahn sebagai jaminan utang untuk mendapatkan pinjaman utang."

\section{Surat Edaran Bank Indonesia}

Menurut Surat Edaran Bank Indonesia No.14/7/DPbS bahwasannya penerbitan surata edaran ini dimaksudkan untuk memberikan acuan kepada perbankan syariah dalam menjalankan produk qardh beragunkan emas yang merupakan pelaksanaan dari Peraturan Bank Indonesia No.10/17/PBI/2008 tentang Produk Bank Umum Syariah dan Unit Usaha Syariah tentang gadai emas. Ketentuan ini berlaku untuk BUS, UUS, dan BPRS. Tujuan penggunaan adalah untuk membiayai keperluan dana jangka pendek atau tambahan modal kerja jangka pendek untuk golongaan nasabah Usaha Mikro dan Kecil (UMK).

Ijma' Ulama

Jumhur ulama menyepakati kebolehan status hukum gadai. Hal dimaksudkan berdasarkan pada kisah Nabi Muhammad SAW yang menggadaikan baju besinya untuk mendapatkan makanan dari seorang yahudi. Para ulama juga mengambil indikasi dari contoh Nabi Muhammad SAW tersebut, ketika beliau beralih dari yang biasanya bertransaksi kepada para sahabat yang kaya kepada seorang yahudi, bahwa hal itu tidak lebih sebagai sikap Nabi Muhammad SAW yang tidak mau memberatkan para sahabat yang biasanya enggan mengambil ganti ataupun harga yang diberikan oleh Nabi Muhammad SAW kepada mereka.

Tabel 1

Perbedaan Gadai Syariah dengan Gadai Konvensional

\begin{tabular}{|l|l|l|}
\hline No & Gadai Syariah & Gadai Konvensional \\
\hline 1. & $\begin{array}{l}\text { Kegiatan usahanya tidak } \\
\text { menerapkan sistem bunga dan } \\
\text { objeknya halal. }\end{array}$ & $\begin{array}{l}\text { Kegiatan usahanya menerapkan sistem } \\
\text { bunga. }\end{array}$ \\
\hline 2. & $\begin{array}{l}\text { Kelebihan lelang barang jaminan } \\
\text { dikembalikan. }\end{array}$ & $\begin{array}{l}\text { Kelebihan lelang barang jaminan tidak } \\
\text { dikembalikan. }\end{array}$ \\
\hline 3. & $\begin{array}{l}\text { Akomodatif atas keanekaragaman } \\
\text { jenis barang jaminan. }\end{array}$ & $\begin{array}{l}\text { Tidak akomodatif atas keanekaragaman } \\
\text { jenis barang jaminan. }\end{array}$ \\
\hline 4. & $\begin{array}{l}\text { Pengawasan oleh DPS dan DSN- } \\
\text { MUI. }\end{array}$ & $\begin{array}{l}\text { Tidak dibawah pengawasan oleh DPS } \\
\text { dan DSN-MUI. }\end{array}$ \\
\hline
\end{tabular}

Nidaul Izzah .... (Prosedur Pengajuan Akad Rahn Pada Emas Batangan Di Pt Bank Syariah) 


\begin{tabular}{|l|l|l|}
\hline 5. & $\begin{array}{l}\text { Penyelesaian perselisihan olah } \\
\text { Basyarnas dan Peradilan Agama. }\end{array}$ & $\begin{array}{l}\text { Penyelesaian perselisihan oleh Badan } \\
\text { Arbitrase Nasioanl Indonesia (BANI) } \\
\text { dan Peradilan Umum. }\end{array}$ \\
\hline
\end{tabular}

Sumber: Ade Sofyan Mulazid, 2016.

\section{Gambar 1}

Skema Rahn

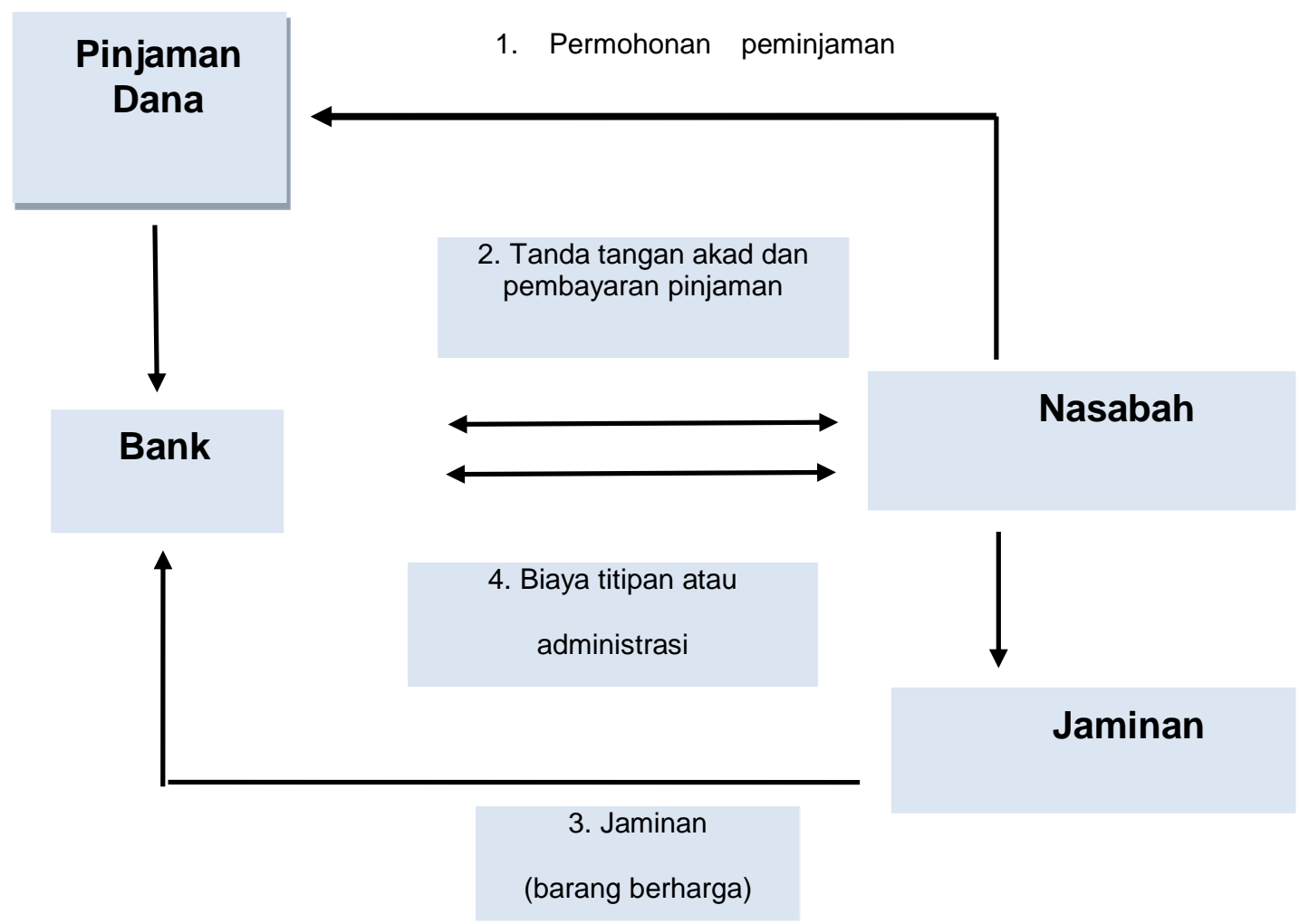

Sumber Prof Dr. H. Suharto, 2012

Penjelasan skema rahn :

a) Nasabah mengajukan akad rahn ke pihak bank dengam membawa kartu identitas dan jaminan berupa emas perhiasan atau batangan.

b) Setelah disetujui oleh pihak bank atas persyaratan nasabah, maka nasabah menandatangani perjanjian tersebut dan pihak bank memberikan pembiayaan.

c) Setelah pembiayaan diterima, nasabah memberikan jaminan kepada pihak bank.

d) Kemudian pihak nasabah membayar atas jasa penitipan jaminan kepada pihak bank.

\section{Metode Penelitian}

Pendekatan dalam penelitian ini adalah penelitian kualitatif. Penelitian ini berusaha mendeskripsikan Prosedur Pengajuan Akad Rahn Pada Emas Batangan di PT Bank Syariah Mandiri Cabang Rawamangun. . Selain itu dalam penelitian ini peneliti sebagai instrumen utama karena peneliti yang merencanakan, melaksanakan, mengumpulkan data, menganalisis data, menarik kesimpulan, dan membuat laporan. Oleh karena itu pendekatan yang digunakan dalam penelitian ini adalah pendekatan kualitatif. Pengumpulan data dilakukan melalui observasi dan wawancara.

\section{Pembahasan}

Prosedur pengajuan akad rahn pada emas batangan di PT Bank Syariah Mandiri Cabang Rawamangun 
Ada beberapa rukun-rukun akad rahn yang harus dipenuhi oleh PT Bank Syariah Mandiri Cabang Rawamangun, antara lain :

a. Ar-Rahin adalah orang yang menggadaikan barang dimana hal ini adalah nasabah.

b. Al-Murtahin adalah orang yang menerima gadai dimana hal ini adalah pihak bank.

c. Al-Marhun adalah barang yang digadai dimana barang yang digadai yaitu berupa emas.

d. Al-Marhun Bih adalah utang dimana utang tersebut adalah pembiayaan yang akan didapat nasabah dari pihak bank.

e. Sighat adalah ijab dan qobul dimana persetujuan antara pihak bank dan nasabah.

Ada beberapa syarat dan ketentuan yang harus dipenuhi nasabah ketika ingin mengajukan pembiayaan gadai emas di PT Bank Syariah Mandiri Cabang Rawamangun, antara lain :

a. Kartu Identitas (KTP).

b. NPWP Nasabah, khusus untuk pembiayaan gadai di atas Rp50 Juta.

c. Jaminan berupa emas perhiasan atau batangan.

d. Memiliki rekening tabungan Bank Syariah Mandiri.

e. Pembiayaan mulai dari Rp.500.000.

f. Jangka waktu minimal 4 bulan dan dapat diperpanjang atau dapat digadai ulang setelah dilakukan penaksiran dan melunasi biaya gadai.

g. Hanya diperuntukkan untuk peorangan.

Berikut ini prosedur untuk bisa mengajukan pembiayaan gadai emas di Bank Syariah Mandiri Cabang Rawamangun, sebagai berikut :

a. Nasabah datang ke kantor cabang untuk mengisi dan menandatangani formulir permohonaan gadai emas dan pengajuan gadai emas ini tidak dapat diwakilkan/dikuasakan oleh petugas bank.

b. Pawning staff menjelaskan karakteristik/fitur produk gadai emas yang meliputi informasi tentang manfaat, biaya, risiko, syarat dan ketentuan produk serta penyelesaian apabila terjadi sengketa serta hak dan kewajiban nasabah termasuk apabila terjadi eksekusi agunan.

c. Pawning Staff melakukan verifikasi keaslian dokumen sesuai ketentuan Bank dengan membubuhkan stempel "copy sesuai asli", tanggal verifikasi dan paraf petugas yang memproses pembiayaan nasabah.

d. Barang jaminan emas diteliti kualitasnya oleh pawning staff untuk menetapkan nilai pembiayaan yang akan diberikan. Nilai pembiayaan yang diberikan jika perhiasan sebesar $80 \%$ dari nilai taksiran sedangkan jika batangan sebesar 95\% dari nilai taksiran.

e. Pawning staff menaksir harga emas yang digadaikan.

f. Kemudian pawning staff melakukan komite ke kantor cabang untuk menentukan diterima atau ditolaknya pembiayaan tersebut.

g. Jika diterima, maka petugas gadai akan menghitung pembiayaan yang akan diterima oleh nasabah sesuai ketentuan Bank Indonesia. sekaligus menentukan biaya administrasi.

Sesuai dengan ketentuan Otoritas Jasa Keuangan (OJK), Pembiayaan qardh beragun emas dapat diberikan paling banyak sebesar 250 juta rupiah dengan jangka waktu pembiayaan paling lama 4 bulan dan dapat diperpanjang. Khusus untuk nasabah usaha mikro dapat diberikan pembiayaan qardh beragun emas sebesar 100 juta rupiah dengan jangka waktu pembiayaan paling lama 18 bulan dengan angsuran setiap bulan.

Berdasarkan Surat Edaran Bank Indonesia Nomor 14/7/DPbs tanggal 29 Februari 2012 perihal Produk Qardh Beragun Emas bagi BUS dan UUS, Financing To Value (FTV) merupakan perbandingan antara jumlah pembiayaan yang didapat nasabah dengan nilai emas yang diagunkan ke bank, yang mengacu dari harga resmi harian yang dikeluarkan oleh PT Aneka Tambang, Tbk. (ANTAM) dengan ketentuan sebagai berikut:

a. Untuk emas batangan paling banyak sebesar $90 \%$ dari rata-rata harga jual emas 100 gram dan harga beli kembali (buyback) emas PT ANTAM.

b. Untuk emas perhiasan paling banyak sebesar $80 \%$ dari rata-rata harga jual emas 100 gram dan harga beli kembali (buyback) emas PT ANTAM. 
Gambar 5

Sampel Harga Emas Batangan

Per tanggal 18 Juli 2018 pada Jam 08:32:09

\begin{tabular}{|l|l|l|}
\hline PRODUK & GRAM & Price per Bar (Rp) \\
\hline Emas Batangan & 1 & 641.000 \\
\hline Emas Batangan & 2 & 1.243 .000 \\
\hline Emas Batangan & 2,5 & 1.543 .000 \\
\hline Emas Batangan & 3 & 1.846 .000 \\
\hline Emas Batangan & 4 & 2.449 .000 \\
\hline Emas Batangan & 5 & 3.062 .000 \\
\hline Emas Batangan & 10 & 6.074 .000 \\
\hline Emas Batangan & 25 & 15.109 .000 \\
\hline
\end{tabular}

Sumber www.logammulia.com

(situs resmi untuk mengetahui harga emas batangan update harian)

\section{Simulasi Gadai Emas}

Pada tanggal 1 Januari 2018, Rany membawa emas batangannya untuk digadaikan dengan berat 20 gram. Berapa pinjaman yang diterima Rany dan berapa biaya yang dibayarkan oleh Rany pada tanggal 1 Mei 2018 ?

Jawab :

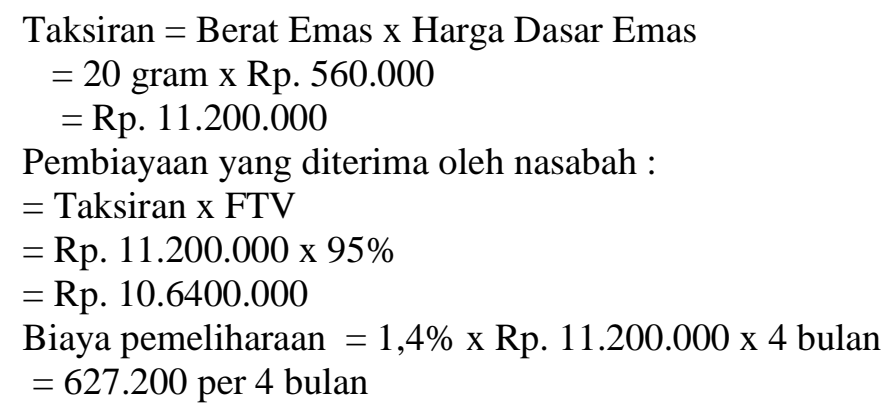

Kendala dalam pelaksanaan prosedur pengajuan akad rahn pada emas batangan di Bank Syariah Mandiri Cabang Rawamangun

Dalam pelaksanaan prosedur pengajuan pembiayaan gadai emas di Bank Syariah Mandiri Cabang Rawamangun ternyata menghadapi kendala-kendala sebagai berikut :

a. Persaingan antar bank yang kompetitif

Sekarang ini sudah cukup banyak berkembang lembaga keuangan syariah seperti BPRS atau BMT serta pegadaian syariah yang menjadi pesaing. Oleh karena itu nasabah bisa mencari nilai pembiayaan atau nilai taksiran emas yang tinggi diantara penawaran harga dari tiap lembaga keuangan syariah.

b. Kurangnya promosi

Produk pembiayaan gadai emas di Bank Syariah Mandiri Cabang Rawamangun belum banyak dikenal masyarakat terutama masyarakat kecil dan menengah ke bawah, hal ini disebabkan karena kurangnya sosialisasi dan promosi ke masyarakat.

Solusi untuk mengatasi kendala dalam pelaksanaan prosedur pengajuan akad rahn pada emas batangan di PT Bank Syariah Mandiri Cabang Rawamangun

a. Pembiayaan dengan akad qardh bisa menjadi salah satu alternatif untuk mendapatkan dana cepat. Akad qardh biasa digunakan untuk menyediakan dana talangan kepada nasabah untuk jangka pendek.

b. Agar banyak masyarakat yang tertarik dan mempercayakan untuk melakukan pembiayaan gadai emas di Bank Syariah Mandiri Cabang Rawamangun, maka diperlukan sosialisasi dan promosi dari pihak bank. Contohnya dengan mengadakan gerai di kampus-kampus, pusat pembelanjaan, pusat bisnis, iklan di media sosial. dan juga dengan menyebarkan brosur-brosur. 


\section{Simpulan}

Berdasarkan dari hasil pembahasan, maka tugas akhir ini dapat disimpulkan sebagai berikut :

1. Ada beberapa syarat-syarat yang harus dipenuhi nasabah ketika ingin mengajukan pembiayaan gadai emas di PT Bank Syariah Mandiri seperti kartu identitas, jaminan berupa emas perhiasan atau batangan, rekening tabungan. Akad rahn dilaksanakan setelah adanya ijab qobul antara bank dan nasabah.

2. Ketika pengajuan produk pembiayaan gadai emas di Bank Syariah Mandiri Cabang Rawamangun ternyata menghadapi 2 kendala yaitu ketidaksesuaian nilai pembiayaan yang didapat dengan kebutuhan nasabah dan banyaknya masyarakat yang belum mengenal akad rahn di lembaga keuangan syariah.

3. Pengajuan akad rahn pada emas batangan di PT Bank Syariah Mandiri Cabang Rawamangun telah sesuai dengan prosedur dan sesuai dengan ketentuan dari Otoritas Jasa Keuangan (OJK).

\section{Saran}

Dari hasil kesimpulan diatas, maka saran penulis sebagai berikut :

1. Sebaiknya Nasabah boleh menerima pembiayaan dengan mata uang asing.

2. Sebaiknya uroh/fee bank dari akad rahn dikurangi atau dipermurah sehingga nilai pembiayaan/nilai taksiran emas bisa lebih tinggi.

3. Perlu adanya evaluasi terkait penyelesaian masalah gadai emas khususnya penetapan nilai taksiran emas yang sesuai dengan harga dasar emas dipasaran.

\section{DAFTAR PUSTAKA}

Afandi, $\quad$ Yazid. 2010. Fiqih Muamalah dan Implementasinya dalam Lembaga Keuangan Syariah. Yogyakarta: Logung Pustaka.

Dr. Kasmir. 2012. Bank Dan Lembaga Keuangan Lainnya. Edisi revisi 2012. Jakarta: PT Raja Grafindo Persada.

Fahmi, Irham. 2015. Pengantar Ilmu Administrasi Bisnis. Cetakan Kesatu.Bandung: CV Alfabeta.

Fatwa Dewan Syariah Nasional Majelis Ulama Indonesia No.25/DSN-MUI/III/2002 Tentang Rahn.

Fatwa Dewan Syariah Nasional Majelis Ulama Indonesia No.26/DSN-MUI/III/2002 Tentang Rahn Emas.

Kamus Besar Bahasa Indonesia Tentang Pengertian Bank

Karim, Adiwarman. 2015. Maqashid Bisnis dan Keuangan Islam. Jakarta: Rajawali Pers.

Makmur dan Rohaya Thahier. 2016. Konseptual dan Kontekstual Administrasi Dan Organisasi Terhadap

Kebijakan Publik. Cetakan Kesatu.Bandung: PT Refika Aditama.

Muhammad. 2016. Manajemen Pembiayaan Bank Syariah. Edisi Kedua. Yogyakarta: UPP STIM YKPN.

Mulyadi, Edisi Keempat. 2016. Sistem Akuntansi. Jakarta: Salemba Empat.

Otoritas Jasa Keuangan. 2012 Tentang Pengertian Gadai

Pernyataan Standar Akuntansi Keuangan No.31

Purnamasari, Evita. 2015. Panduan Menyusun SOP Standart Operating Procedure. Jakarta: Komunitas Bisnis.

Sholahuddin, Muhammad. 2011. Ekonomi Keuangan dan Bisnis Syariah. Jakarta: PT Gramedia Pustaka Utama.

Soetjipto. 2015. Mengembangkan Koperasi. Edisi Kelima. Yogyakarta:Cahaya Atma Pustaka.

Sofyan, Ade. 2016. Kedudukan Sistem Pegadaian Syariah. Jakarta: Prenadamedia Group.

Syafiie, Inu Kencana dan Welasari. 2015. Ilmu Administrasi. Cetakan Kesatu. Yogyakarta: Pustaka Pelajar.

Undang-undang Hukum Perdata Pasal 1150 Tentang Pengertian Gadai

Undang-undang Peraturan Bank Indonesia No.11/3/PBI/2009 Tentang Bank Umum Syariah

Undang-undang Peraturan Bank Indonesia No.11/10/PBI/2009 Tentang Unit Usaha Syariah

Undang-undang Republik Indonesia No.10. 1998 Pasal 1 dan 2

Undang-undang Republik Indonesia No.21. 2008 